\title{
Absorption, Accumulation and Export of Macronutrients by Common Bean Irrigated, and Influenced by Nitrogen Fertilization
}

\author{
Rodinei Facco Pegoraro ${ }^{1}$, Dário Oliveira ${ }^{1}$, Guilherme Borém Lobato Moreira ${ }^{1}$, Marcos Koiti Kondo ${ }^{1}$, Victor \\ Martins Maia ${ }^{1} \&$ Neiva Maria Batista Vieira ${ }^{2}$ \\ ${ }^{1}$ Agrarian Science Departament, State University of Montes Claros, MG, Brazil \\ ${ }^{2}$ Federal Institute of Education, Science and Technology of the South of Minas Gerais-IFET, Machado-MG, \\ Brazil \\ Correspondence: Rodinei Facco Pegoraro, Agrarian Science Departament, State University of Montes Claros, MG, \\ Brazil. E-mail: rodinei_pegoraro@yahoo.com.br
}

Received: February 17, 2013 Accepted: March 18, 2013 Online Published: October 15, 2013

doi:10.5539/jas.v5n11p34 URL: http://dx.doi.org/10.5539/jas.v5n11p34

\begin{abstract}
The study was aimed at evaluating the absorption, accumulation and export of macronutrients, as well as the interference of the addition of $\mathrm{N}$ doses in the absorption of macronutrients by common bean (Phaseolus vulgaris L.) irrigated. This study was conducted using $4 \times 4$ factorial design, which included four nitrogen doses in seedling $(0$, 40,80 and $\left.120 \mathrm{~kg} \mathrm{ha}^{-1}\right)$ and four sidedressing nitrogen doses $\left(0,40,80\right.$ and $\left.120 \mathrm{~kg} \mathrm{ha}^{-1}\right)$. A second study was made to evaluate the curve of absorption of nutrients, with eight treatments defined per time of plant sampling on days after the emergence (DAE)-10, 20, 30, 40, 50, 60, 70 and 80 DAE. Nutrient content absorbed by leaves, stem, bark and flower, seeds and shoot were characterized at the end of bean cycle. The absorption of nitrogen (N), potassium $(\mathrm{K})$ and calcium $(\mathrm{Ca})$ increased with the addition of doses of $\mathrm{N}$ between 40 and $80 \mathrm{~kg} \mathrm{ha}^{-1}$, and decreased at largest dose of $\mathrm{N}\left(120 \mathrm{~kg} \mathrm{ha}^{-1}\right)$ in sidedressing, suggesting the occurrence of phytotoxic effect in common bean by excess of $\mathrm{N}$. The rate of maximum accumulation of nutrients in the leaves of bean was obtained between 28 and $31 \mathrm{DAE}$ (R5-R6 stages). The absorption and export of nutrients in the shoot and seeds had the following order: $\mathrm{K}>\mathrm{N}>\mathrm{Ca}>\mathrm{S}>\mathrm{P}>\mathrm{Mg}$, and obtained in the shoot the accumulation of 136,118, 82, 21, 13 and $12 \mathrm{~kg} \mathrm{ha}^{-1}$, respectively. Seeds were the component of plant with highest macronutrients accumulation, suggesting a high export rate of nutrients by the crop.
\end{abstract}

Keywords: Macronutrient interaction, macronutrient absorption curve, plant components, plant growth

\section{Introduction}

Phaseolus vulgaris L. is a very demanding plant as regards nutrients, very sensitive to climate factors and very susceptible to plagues and diseases (Zucareli et al., 2011). Low productivity is observed, mainly in the traditional cultivation season (rainy season) with sowing in October-November, outcome of the inadequate management techniques (low quality seeds, poor weed control, pests and diseases), climate variability and the continuous depletion of soil fertility (Fageria, 2002; Zucareli et al., 2006). However, high potential yield has been showed in irrigated crops, during autumn and winter seasons, in the Northern Minas Gerais, virtually without nutritional demand information.

The absence of information from cultivars with high potential yields are connected to few research studies carried out many years ago (Haag et al., 1967) and involve very different cultivars from those currently used by the farmers.

In 2003 and 2004, Magic Valley, Idaho, USA, 16 common bean genotypes, under conventional irrigated system showed average plant absorption of 148,20 and $108 \mathrm{~kg} \mathrm{ha}^{-1}$ of nitrogen $(\mathrm{N})$, phosphorus $(\mathrm{P})$ and potassium $(\mathrm{K})$, respectively (Westermann et al., 2011). For the Bribri variety, with a stand of 156000 plants ha $^{-1}$ and a dry weight of plants (shoot and roots) of $4227 \mathrm{~kg} \mathrm{ha}^{-1}$, pods extracted $37 \%, 52 \%, 39 \%, 11 \%$ and $32 \%$ of N, P, K, calcium (Ca) and magnesium $(\mathrm{Mg})$, respectively, from $156(\mathrm{~N}), 24(\mathrm{P}), 222(\mathrm{~K}), 117(\mathrm{Ca})$ and $26(\mathrm{Mg}) \mathrm{kg} \mathrm{ha}^{-1}$ of total absorption (Bertsch et al., 2003).

Associated studies with the absorption and export of nutrients by bean, during the different phenological stages and at the end of the cultivation cycle, are fundamental to support strategies to define the doses and the split 
fertilization during growing, and the minimum doses that must be replaced to the soil for the purposes of maintenance of fertility (Araújo \& Teixeira, 2008). This will contribute to the increased efficiency in handling the crop, providing productivity gains and reduced costs in the field, through the reasonable and efficient use of the inputs and the soil (Anghinoni, 2007). Working with two cultivars of beans and two plantation systems, Andrade et al. (2009), observed that the contents of nutrients absorbed and exported by seeds in the cultivation area followed the order: $\mathrm{N}>\mathrm{K}>\mathrm{Ca}>\mathrm{Mg}>\mathrm{P}>\mathrm{S}$ and Fageria et al. (2008) obtained the following order: $\mathrm{N}>\mathrm{K}>\mathrm{Ca}>\mathrm{P}>\mathrm{Mg}$. However, Albuquerque et al. (2011a) obtained the following top-down order: $K>N>P$, and Pessoa et al. (2000) observed the following top-down order of export of nutrients: $\mathrm{N}>\mathrm{Ca}>\mathrm{K}>\mathrm{P}>\mathrm{Mg}$, and observed the removal of up to $72 \mathrm{~kg} \mathrm{ha}^{-1}$ of $\mathrm{N}$ through seeds, corroborating the high nitrogen demand by bean.

Nitrogen is one of the main nutrients by beans, especially for increasing the productivity and production of biomass (Lima et al., 2001; Nascimento et al., 2009; Teixeira et al., 2010; Albuquerque et al., 2012; Maia et al., 2012) and nutrient absorption (Fageria \& Baligar, 2005; Teixeira et al., 2010). Teixeira et al. (2010) observed that the application of $\mathrm{N}$ in sidedressing $\left(0-120 \mathrm{~kg} \mathrm{~h}^{-1}\right)$ promoted linear increments in the $\mathrm{N}$ and $\mathrm{Mg}$ contents in beans with no-tillage and Rajesh et al. (2011a) showed N increase in shoot. According to Kikuti et al. (2006) the fertilization with $\mathrm{N}$ and $\mathrm{P}$ in bean BRS-MG Talismã increase N, P and $\mathrm{K}$ content in leaves and petioles, and, decrease $\mathrm{K}$ and sulphur $(\mathrm{S})$ content in flowers and strings but the nutritional contents still remained in the level considered as adequate. However, the use of higher $\mathrm{N}$ doses with urea fertilizer may result in absorption deficit of $\mathrm{P}, \mathrm{K}, \mathrm{Ca}, \mathrm{Mg}$ and $\mathrm{S}$ by plants, because of excessive absorption of $\mathrm{NH}_{4}^{+}$.

Nutrient absorption restriction by excessive ammonium fertilization in sensitive plants is justified by competitive inhibition in the cations $\mathrm{K}^{+}$transport protein, reducing the primary influx and internal distribution of nutrients, at both whole-plant and cellular levels (Szczerba et al., 2008); The ammonium uptake for roots bring to $\mathrm{H}^{+}$release and a subsequent reduction in the concentration of dicarboxylic acids by decarboxylation, a cellular response to maintain cytoplasmic $\mathrm{pH}$, decreasing cation absorption and favoring anion absorption (Hoopen et al., 2010). A high energy consumption (photoassimilates) in the root cells, due to increase $\mathrm{NH}_{4}{ }^{+}$efflux, reduces plant growth and nutrients absorption in ammonium phytotoxic conditions (Brito et al., 2001; Brito \& Kronzucker, 2006).

The implementation of studies that identify changes in the absorbed content of nutrients provoked by changes in the supply of $\mathrm{N}$ for plants may contribute to adjustment of new doses of nutrients for high-productivity common beans. This study aimed at calculating the absorption of nutrients during the phenological cycle, and the accumulation and export of nutrients after the addition of increasing doses of nitrogen in seedling and sidedressing of winter common bean in the north of Minas Gerais.

\section{Material and Methods}

The experiment was carried out in a Red Eutrophic Latosol (Embrapa, 2006), of average texture in the municipality of Janaúba, north of the state of Minas Gerais. The climate, according to Köppen (Ometto, 1981) is of the Aw type (tropical wet, savanna with dry winter).

The soil preparation comprised one plowing and two harrowing. The soil correction was carried out through evaluation of the need indicated by soil analysis, which presented the following characteristics: $\mathrm{pH}$ in $\mathrm{H}_{2} \mathrm{O}(1: 2,5$ dilution of soil: water $=5.9$; Organic carbon $=2.9 \mathrm{dag} \mathrm{kg}^{-1} ; \mathrm{P}\left(\right.$ Mehlich-1) $=6.5 \mathrm{mg} \mathrm{dm}^{-3} ; \mathrm{K}=141 \mathrm{mg} \mathrm{dm}^{-3} ; \mathrm{Ca}=3.3$ $\mathrm{cmol}_{\mathrm{c}} \mathrm{dm}^{-3} ; \mathrm{Mg}=0.7 \mathrm{cmol}_{\mathrm{c}} \mathrm{dm}^{-3} ; \mathrm{Al}=0.0 \mathrm{cmol}_{\mathrm{c}} \mathrm{dm}^{-3} ; \mathrm{H}+\mathrm{Al}=1.3 \mathrm{cmol}_{\mathrm{c}} \mathrm{dm}^{-3} ; \mathrm{SB}=4.3 \mathrm{cmol}_{\mathrm{c}} \mathrm{dm}^{-3} ; \mathrm{t}=4.3 \mathrm{cmol}_{\mathrm{c}} \mathrm{dm}^{-3}$; $\mathrm{T}=5.6 \mathrm{cmol}_{\mathrm{c}} \mathrm{dm}^{-3} ; \mathrm{B}=10.1 \mathrm{mg} \mathrm{dm}^{-3} ; \mathrm{Cu}=58.6 \mathrm{mg} \mathrm{dm}^{-3} ; \mathrm{Fe}=113.3 \mathrm{mg} \mathrm{dm}^{-3} ; \mathrm{Mn}=177.9 \mathrm{mg} \mathrm{dm}^{-3} ; \mathrm{Zn}=4.0 \mathrm{mg} \mathrm{dm}^{-3} ; \mathrm{e}$ $\mathrm{S}=42.3 \mathrm{mg} \mathrm{dm}^{-3}$; P-rem=29.0 $\mathrm{mg} \mathrm{L}^{-1} \mathrm{e} \mathrm{V}=77 \%$. Soil analysis methods used are described in Embrapa (1997).

The seedling of common bean, cultivar Pérola, was carried out manually, during the autumn-winter period, in April-May 2009, under the conventional cultivation system, using 14 seeds per linear meter, with line spacing of $0.50 \mathrm{~m}$. The experiment was kept free of weed by chemical and mechanical method, and the other crop treatments were those typically dedicated to the crop in the region. Disease and plague control was performed through the application of products recommended for the crop. Conventional sprinkler irrigation was carried out with average precipitation estimated in $3.0 \mathrm{~mm} \mathrm{hour}^{-1}$, and handled according to the crop needs $(\mathrm{Kc})$ during the development stages. Low volumes of rain were observed in April and May, and the average temperature obtained between April and July was $24^{\circ} \mathrm{C}$ (Figure 1). 


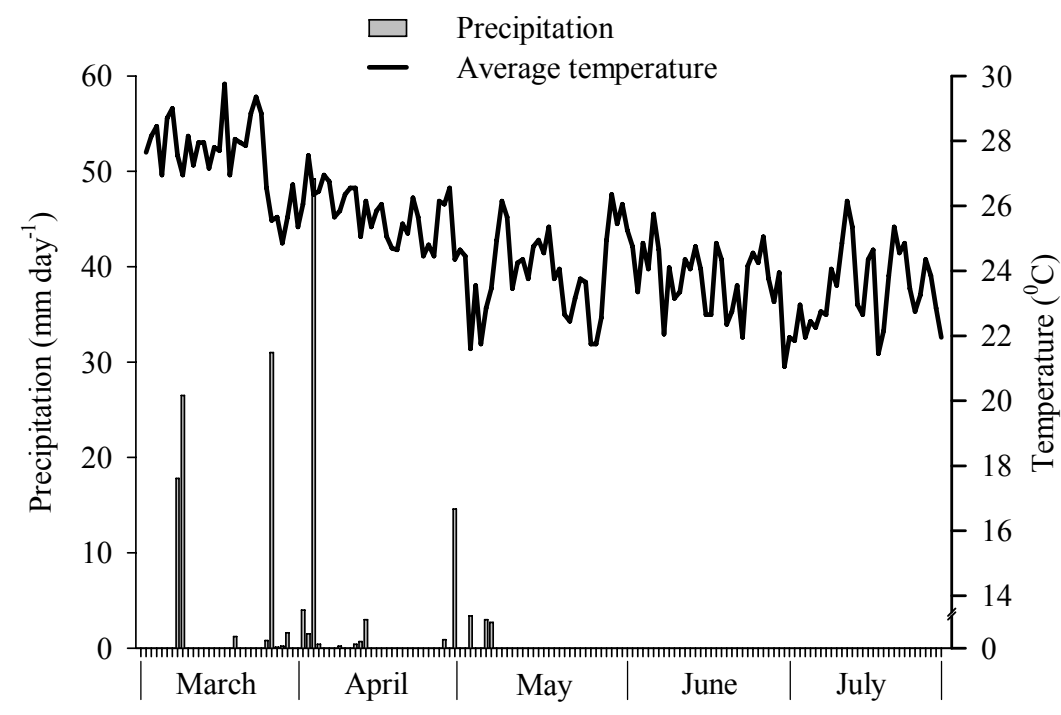

Figure 1. Pluvial precipitation $\left(\mathrm{mm} \mathrm{day}^{-1}\right)$ and average temperature $\left({ }^{\circ} \mathrm{C}\right)$ for the period March - July 2009. Janaúba, state of Minas Gerais. Source: INMET (2012)

Each portion was composed of 6 lines of length 5 meters, with 0.5 -meter spacing between the lines, totalizing 15 $\mathrm{m}^{2}$. The two central lines were used for experimental evaluation of the content of nutrients absorbed by the crop.

In the first study, to evaluate the effect of nitrogen fertilization in the absorbed content of nutrients at the end of the common bean cycle, we used the statistical design in randomized blocks with three replications and $4 \mathrm{x} 4$ factorial design, corresponding to four nitrogen doses (urea source) in seedling $\left(0,40,80\right.$ and $\left.120 \mathrm{~kg} \mathrm{ha}^{-1}\right)$ and four sidedressing nitrogen doses $\left(0,40,80\right.$ and $\left.120 \mathrm{~kg} \mathrm{ha}^{-1}\right)$, incorporated to the soil, on 20 days after emergence (DAE).

In the second study, to evaluate the absorption of nutrients during the development of the crop, we chose to sample the plants in the two central rows, by means of a flush cut every 10 days and after the 10th DAE, totalizing eight samples. The study followed the randomized blocks design, with three replications. After the sampling, the shoot of the common bean was separated into four components: leaves, stem, flower + bark and seeds, and taken to the forced air circulation oven at $65^{\circ} \mathrm{C}$ for drying and further weighing of the materials collected.

The fertilization recommendation (except for the $\mathrm{N}$ ) and liming for the bean crop, was carried out to obtain higher productivity than 2,500 $\mathrm{kg} \mathrm{ha}^{-1}$ (technological level $4-\mathrm{NT}_{4}$ ), according to Chagas et al. (1999), and corresponded to doses of $20 \mathrm{~kg} \mathrm{ha}^{-1}$ of $\mathrm{K}_{2} \mathrm{O}$, as potassium chloride, $110 \mathrm{~kg} \mathrm{ha}^{-1}$ of $\mathrm{P}_{2} \mathrm{O}_{5}$ as single superphosphate, $1 \mathrm{~kg} \mathrm{ha}^{-1}$ of B, using boric acid as source, and $60 \mathrm{~g} \mathrm{ha}^{-1}$ of Mo as sodium molybdate, between 15 and 25 DAE. Due to the soil chemical analysis results, liming was not necessary. In the study of course of absorption of nutrients, $120 \mathrm{~kg} \mathrm{ha}^{-1}$ of $\mathrm{N}$ was added, portioned with $40 \mathrm{~kg} \mathrm{ha}^{-1}$ in seedling, and the remainder in sidedressing, up to 20 DAE.

After drying in oven, plant samples were crushed in Willey-type grinder, sifted $(2 \mathrm{~mm})$ and homogenized for quantification of the macronutrients in the different plant components, as described by Bataglia et al. (1983). In order to calculate the accumulation of nutrients, the content obtained $\left(\mathrm{dag} \mathrm{kg}^{-1}\right)$ was multiplied by the dry matter weight in each plant component $\left(\mathrm{kg} \mathrm{ha}^{-1}\right.$ ) and divided by 100 (unit conversion factor), to obtain the content of nutrients absorbed by the common bean in $\mathrm{kg} \mathrm{ha}^{-1}$.

The export of nutrients was calculated by the relationship between the content of nutrients contained in the seed during the harvest and its dry matter weight. The accumulation rates were calculated from the equations adjusted for the accumulation of each of the nutrients.

The data collected were submitted to variance analysis through the statistical analysis software Sisvar ${ }^{\text {(Ferreira, }}$ 2000). The effects of the nitrogen doses in seedling and in sidedressing were evaluated by regression analysis, with adjustment of representative curves for each of the characteristics evaluated.

The times, in days interval, were taken into account as a parameter for plant collection. Therefore, as these are quantitative data, there is a functional correlation between $\mathrm{x}$ (DAE) and $\mathrm{y}$ (response variable). The model selection occurred according to the adjustment (percentage of explained variance, $\mathrm{R}^{2}$ ) and best representation of the 
phenomenon. The non-linear regression model selected to represent the production of biomass in the components of the common bean and accumulation of nutrients in the leaves, stem and bark + flower was the Gaussian with three parameters, according to equation below:

$$
\hat{y}=a e^{\left[-0.5\left(\frac{x-x_{0}}{b}\right)^{2}\right]}
$$

where:

$\mathrm{a}=$ corresponds to the maximum accumulation value

$\mathrm{x}_{0}=$ corresponds to the value of $\mathrm{x}$, in DAE to obtain the maximum accumulation of nutrients.

$\mathrm{b}=$ corresponds to the range in the value of $\mathrm{x}$, in DAE, between the inflection point and the maximum point.

Thus, from the adjusted model it was possible to accurately determine the value of the inflection point (IP) in the curve as follows:

$$
\mathrm{IP}=\mathrm{x}_{\mathrm{o}}-\mathrm{b}
$$

Mathematically, the IP corresponds to the value of $\mathrm{x}$ where the curvature of the adjusted model changes its signal; in practical terms, it corresponds to the value of $\mathrm{x}$, in DAE, where the daily accumulation rate, even if positive, may decrease.

The non-linear regression model selected to represent the production of seeds, total biomass and accumulation of nutrients in the seeds and the shoot (sum of components) was the sigmoid with three parameters, according to equation below:

$$
\hat{y}=\frac{a}{1+e\left[-\left(\frac{x-x_{0}}{b}\right)\right]}
$$

where:

$\mathrm{a}=$ corresponds to the maximum accumulation value

$\mathrm{x}_{0}=$ corresponds to the value of $\mathrm{x}$, in DAE, for the beginning of curve inflection (inflection point, where the maximum accumulation rate of dry matter or nutrients occurs).

$\mathrm{b}=$ corresponds to the range in the value of $\mathrm{x}$, in DAE, in which the highest variation of $\mathrm{y}$ (production of dry matter or accumulation of nutrients occurs).

\section{Results and Discussion}

\subsection{Accumulation of Macronutrients in Common Beans After Nitrogen Fertilization in Seedling and Sidedressing}

The content of nutrients absorbed by the shoot of the bean at the end of the cycle was influenced significantly $(\mathrm{p}<0.01)$ only by $\mathrm{N}$ doses in sidedressing (Table 1$)$. The addition of $\mathrm{N}$ doses in sidedressing incremented the $\mathrm{N}, \mathrm{K}$, $\mathrm{Ca}$ content absorbed by the bean in intermediate doses, and reduced the content absorbed in the largest dose of $\mathrm{N}$ applied, $120 \mathrm{~kg} \mathrm{ha}^{-1}$ (Figure 2), suggesting possible phytotoxic effect of the single addition of doses equal or superior to $120 \mathrm{~kg} \mathrm{ha}^{-1}$ in sidedressing, as for the growth and absorption of nutrients by the bean. According to Oliveira et al. (2003) larger $\mathrm{N}$ doses (above $60 \mathrm{~kg} \mathrm{ha}^{-1}$ applied in sidedressing through the leaves or through Red Yellow Eutrophic Latosol, average texture) imply the stabilization and dropped yield of green seed string and dry seeds, due to the toxic effect of ammonium $\left(\mathrm{NH}_{4}^{+}\right)$derived from urea, and reducing the absorption of other ions, such as $\mathrm{K}^{+} \mathrm{Ca}^{++}$and $\mathrm{Mg}^{++}$by the competitive effect between the ions by the plant absorption sites. The main hypotheses have been linked to physiological changes associated with $\mathrm{NH}_{4}^{+}$assimilation and ion imbalances resulting from decreased uptake of essential cations such as $\mathrm{K}^{+}, \mathrm{Mg}^{2+}$, and $\mathrm{Ca}^{2+}$ (Kronzucker et al., 2001; Brito \& Kronzucker, 2006; Hoopen et al., 2010).

The mechanisms also are connected with the inhibitory efficiency of $\mathrm{NH}_{4}{ }^{+}$in occupy the channels of low-affinity transporters "low-affinity transport system" (LATS), primarily by inhibiting the internal transport of $\mathrm{K}^{+}$from roots to shoots of sensitive plants to excess ammonium (Holzschuh et al., 2009; Szczerba et al., 2008).

The increased availability of $\mathrm{NH}_{4}{ }^{+}$in the soil solution can result in the accumulation of large amounts of $\mathrm{NH}_{4}^{+}$in the plant, both on a tissue basis, and, specifically, in the cytosol of root cells, implicating in two toxic effects in plants (Britto \& Kronzucker, 2006). First, tissue (and cytosolic, in some cases) concentrations of nutritionally important cations such as $\mathrm{K}^{+}, \mathrm{Ca}^{2+}$, and $\mathrm{Mg}^{2+}$ drop significantly with $\mathrm{NH}_{4}^{+}$excess, resulting in pathological conditions with symptoms similar to those under deprivation of these nutrients. Second, increased $\mathrm{NH}_{4}{ }^{+}$influx is 
strongly associated with an even greater increase in $\mathrm{NH}_{4}{ }^{+}$efflux (with efflux approaching 100\% of influx). Efflux transporters appear to release function of excessive amounts of this ion from root cells, similar to antibiotic-resistant bacteria pumping lethal substances out of the cell. Because of the $\mathrm{NH}_{4}^{+}$efflux, there is an increase in respiratory oxygen and photoassimilates consumption, resulting in growth reduction of plants $\mathrm{NH}_{4}^{+}$ sensitive (Kronzucker et al., 2001).

Table 1. Summarized variance analysis of the data related to the accumulation of macronutrients $\mathrm{N}, \mathrm{P}, \mathrm{K}, \mathrm{Ca}, \mathrm{Mg}$, $\mathrm{S}$ of common bean in relation to the $\mathrm{N}$ doses in plantation and sidedressing

\begin{tabular}{|c|c|c|c|c|c|c|c|}
\hline \multirow{2}{*}{ Fixed variable } & \multirow{2}{*}{$\mathrm{GL}^{\psi}$} & \multicolumn{6}{|c|}{ Mean square } \\
\hline & & $\mathrm{N}$ & $\mathrm{P}$ & $\mathrm{K}$ & $\mathrm{Ca}$ & $\mathrm{Mg}$ & $\mathrm{S}$ \\
\hline Block & 2 & 213.77 & 2.02 & 343.31 & 268.33 & 5.59 & 4.28 \\
\hline $\mathrm{N}$ sidedressing (Ncob) & 3 & $1,447.50 * *$ & $17.02^{\mathrm{ns}}$ & $2,359.66^{* *}$ & $990.92 * *$ & $31.27^{\mathrm{ns}}$ & $71.93^{\mathrm{ns}}$ \\
\hline $\mathrm{N}$ seedling (Nsem) & 3 & $685.72^{\mathrm{ns}}$ & $17.24^{\mathrm{ns}}$ & $465.89^{\mathrm{ns}}$ & $331.78^{\mathrm{ns}}$ & $14.27^{\mathrm{ns}}$ & $24.80^{\mathrm{ns}}$ \\
\hline Nsem versus Ncob & 9 & $973.25^{\mathrm{ns}}$ & $9.63^{\mathrm{ns}}$ & $391.59^{\mathrm{ns}}$ & $587.11^{\mathrm{ns}}$ & $9.36^{\mathrm{ns}}$ & $39.88^{\mathrm{ns}}$ \\
\hline Residue & 30 & 312.17 & 4.47 & 330.65 & 154.85 & 6.76 & 17.47 \\
\hline $\mathrm{CV}(\%)^{\neq}$ & & 15.51 & 20.33 & 26.07 & 15.24 & 22.23 & 21.00 \\
\hline Average $\left(\mathrm{kg} \mathrm{ha}^{-1}\right)$ & & 113.91 & 10.40 & 70.40 & 81.60 & 11.70 & 19.90 \\
\hline
\end{tabular}

** ${ }^{\text {ns }}$ : significant at $1 \%$ and non significant by $\mathrm{F}$ test, respectively. ${ }^{\psi}$ : degrees of freedom. ${ }^{\neq}$: coefficient of variation in percentage.

Studies with nitrogen fertilization also observed increment in the content of nutrients after the addition of $\mathrm{N}$ doses (Aulakh \& Malhi, 2005). In two years of study, Farinelli et al. (2006) obtained linear response, in the first year, up to the dose of $160 \mathrm{~kg} \mathrm{ha}^{-1}$, and quadratic response in the second year, reaching maximum value in the dose of 122.8 $\mathrm{kg} \mathrm{ha}^{-1}$ of $\mathrm{N}$. Carvalho et al. (2003) observed that the measure increases the $\mathrm{N}$ dose applied to the soil, in sidedressing, there was increment in the content of $\mathrm{N}$ in the leaves, corresponding to the accumulation of $115 \mathrm{~kg}$ $\mathrm{ha}^{-1}$ of $\mathrm{N}$, being this one reached in the dose of $108 \mathrm{~kg} \mathrm{ha}^{-1}$ of N. And Kaneko et al. (2010) and Teixeira et al. (2010) who, studying the use of different $\mathrm{N}$ doses in sidedressing for the cultivar Pérola and BRS-MG Talismã, obtained linear responses for the content of $\mathrm{N}$ accumulated of the common bean. 

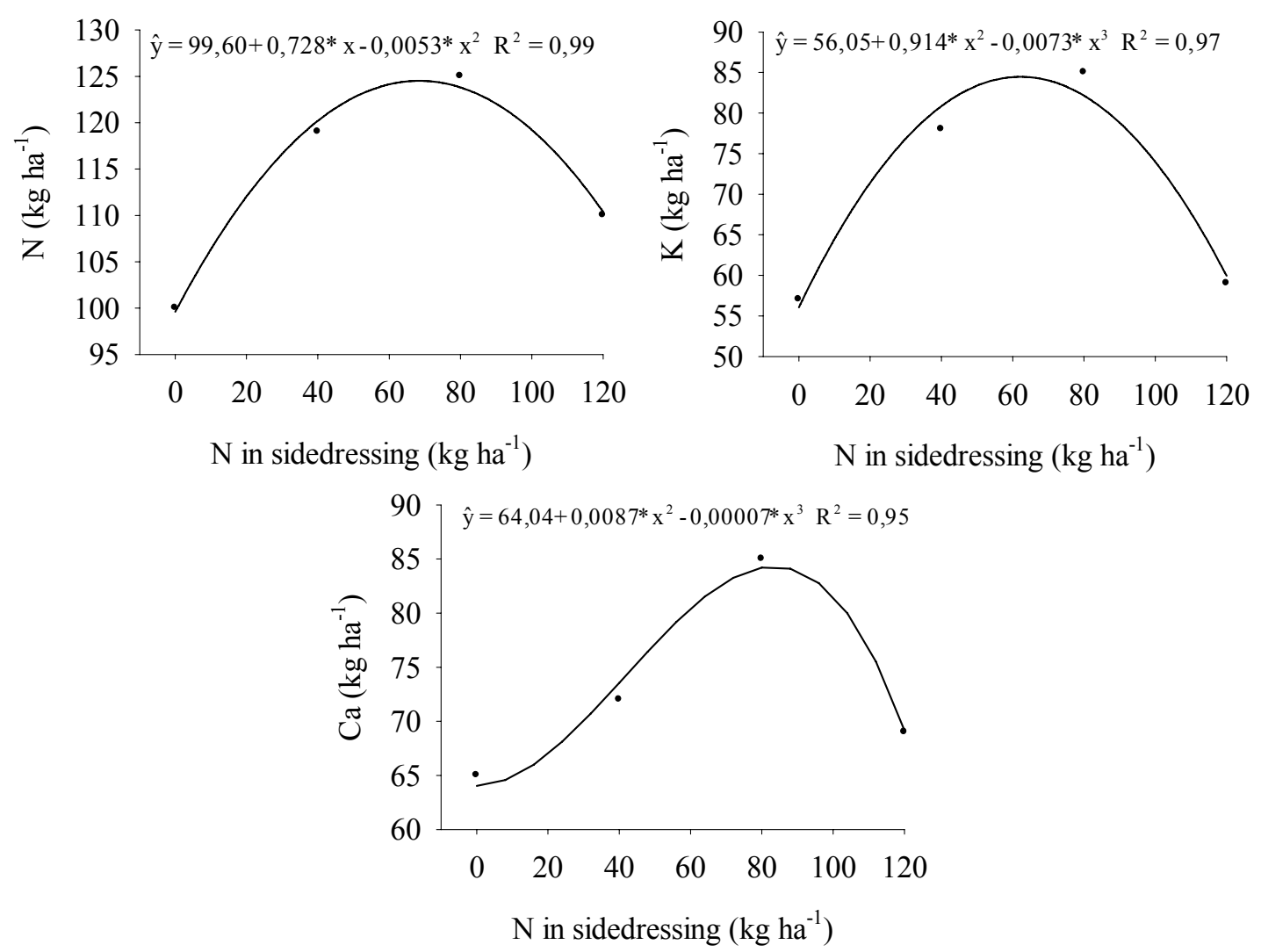

Figure 2. Accumulation of $\mathrm{N}, \mathrm{K}$ and $\mathrm{Ca}$ in the common bean cv. Pérola, due to $\mathrm{N}$ doses in sidedressing, in conventional plantation system

The maximum content of $\mathrm{K}$ absorbed by the plants due to $\mathrm{N}$ doses was $78 \mathrm{~kg} \mathrm{ha}^{-1}$ and corresponded to the addition of $68 \mathrm{~kg} \mathrm{ha}^{-1}$ of $\mathrm{N}$ in sidedressing (Figure 2), and the content of $\mathrm{K}$ absorbed by the bean ranged from 64 to $78 \mathrm{~kg}$ $\mathrm{ha}^{-1}$, being considered as compatible to results found in the literature. Andrade et al. (2009) and Oliveira et al. (2002) obtained average accumulation of 81 and $56 \mathrm{~kg} \mathrm{ha}^{-1}$ of $\mathrm{K}$, respectively, in their studies.

The content of $\mathrm{Ca}$ absorbed after the addition of $\mathrm{N}$ doses had maximum absorption with the addition of $86 \mathrm{~kg} \mathrm{ha}^{-1}$ in the dose of $80 \mathrm{~kg} \mathrm{ha}^{-1}$ of $\mathrm{N}$ in sidedressing (Figure 2). This result corroborates those by Oliveira et al. (2002), who worked with cultivar carioca planted on different vegetable residues and different $\mathrm{N}$ doses in sidedressing, had the accumulation of $100 \mathrm{~kg} \mathrm{ha}^{-1}$ of Ca as response. However, the accumulated values of $\mathrm{Ca}$ are found above the sufficiency range of 30 to $40 \mathrm{~kg} \mathrm{ha}^{-1}$, proposed by Malavolta et al. (1997), and corroborate the sufficiency range proposed by Martinez et al. (1999), of 50 to $90 \mathrm{~kg} \mathrm{ha}^{-1}$.

$\mathrm{N}$ was the macronutrient absorbed in larger quantities by the bean, with the content $114 \mathrm{~kg} \mathrm{ha}^{-1}$. This result is similar to the one found by Sant'ana et al. (2011) who worked with different $\mathrm{N}$ doses ranging from 0 to $240 \mathrm{~kg} \mathrm{ha}^{-1}$, obtained $\mathrm{N}$ absorption in the shoot superior to $100 \mathrm{~kg} \mathrm{ha}^{-1}$ in the dose $157 \mathrm{~kg} \mathrm{ha}^{-1}$. However, Santos \& Fageria (2007) obtained accumulations between 41 and $120 \mathrm{~kg} \mathrm{ha}^{-1}$ of $\mathrm{N}$ in the shoot (seeds + vegetative parts) when they studied four cultivars of common bean and different nitrogen fertilization handling in seedling and sidedressing. According to Arf et al. (2004) variations in the absorption of $\mathrm{N}$ by plants depend on several factors, such as the content of $\mathrm{N}$ available in the soil, mineralization rate of the organic matter, temperature, symbiotic fixation of $\mathrm{N}_{2}$, cultivar etc.

The nutrient absorption with adequate biomass production is resulted from balanced nutrient supply and the ideal conditions of soil and water management, among other factors. Rajesh et al. (2012a) and Rajesh et al. (2012b) observed a nutrient concentration increase with optimum conditions: water potential of -422 to $-171 \mathrm{kPa}, 5.5$ to 6.1 soil $\mathrm{pH}, 50$ to $68 \mathrm{mg} \mathrm{kg}^{-1}$ of $\mathrm{N}$, and 38 to $40 \mathrm{mg} \mathrm{kg}^{-1}$ of $\mathrm{P}$, respectively for Kentucky bluegrass and white clover crop system in pot experiment, highlight the importance of balanced nutrient supply, liming and water to increase dry matter yield.

The content of $\mathrm{P}, \mathrm{Mg}$ and $\mathrm{S}$ was not influenced by $\mathrm{N}$ doses in seedling and sidedressing (Table 1), and average 
accumulations of 10,12 and $20 \mathrm{~kg} \mathrm{ha}^{-1}$, respectively, were observed. Such results may be regarded as compatible to those describe in the literature (Oliveira et al., 2002; Neves et al., 2009), where variations in the content of $\mathrm{P}$ between 9 and $18 \mathrm{~kg} \mathrm{ha}^{-1}$, of $\mathrm{Mg}$ between 9 and $21 \mathrm{~kg} \mathrm{ha}^{-1}$ and of S between 8 and $26 \mathrm{~kg} \mathrm{ha}^{-1}$ were observed.

The average contents of $\mathrm{N}, \mathrm{P}, \mathrm{K}, \mathrm{Ca}, \mathrm{Mg}$ and $\mathrm{S}$ absorbed by the shoot of the bean were according to those determined by Andrade et al. (2009), working with the cv. Ouro Negro and Talismã, and Oliveira et al. (2002), who differed only as regards the lower extraction of $\mathrm{S}$, which was 8 and $9 \mathrm{~kg} \mathrm{ha}^{-1}$, respectively.

\subsection{Production of Biomass and Absorption of N, P, K During the Common Bean Development Cycle}

During the development of the bean, we obtained high production of dry matter mass of the shoot and, as from the 20 DAE, development stage V4, up to the 55 DAE, between stages R7-R8, when the maximum biomass accumulation rate decreased exponentially until the end of the crop cycle (Figure 3 and Table 2), moment in which we obtained maximum production of $2,968 \mathrm{~kg} \mathrm{ha}^{-1}$ of bean seeds. Such results suggest that the winter bean irrigated presented high production of biomass and, therefore, absorption of nutrients in the period of 20 to 55 DAE, and the sidedressing fertilization handling is more important in the beginning of the stage with highest nutritional demand by the plant, comprised especially between 20 and 30 DAE.

The maximum relative leaf production was observed at the end of the bean plant vegetative stage, between 20 and 30 DAE (Figure 3); we further observed intense decrease in the proportion of leaves a and the incremented production of reproductive components, such as flower, strings and seeds. We obtained maximum rate of accumulation of flower and bark of the strings (bark + flower) at the 57 DAE, moment in which the plant, possibly intensified the translocation of photoassimilates for the production of seeds (Table 2 and Figure 3). According to Brito et al. (2011) the common bean presents two important stages of dry matter mass accumulation: one of quick incrementation from the blooming (38 DAS) until reaching a maximum, in the beginning of string maturation (68 DAS), and one of small decline in the final maturation stage (78 DAS).
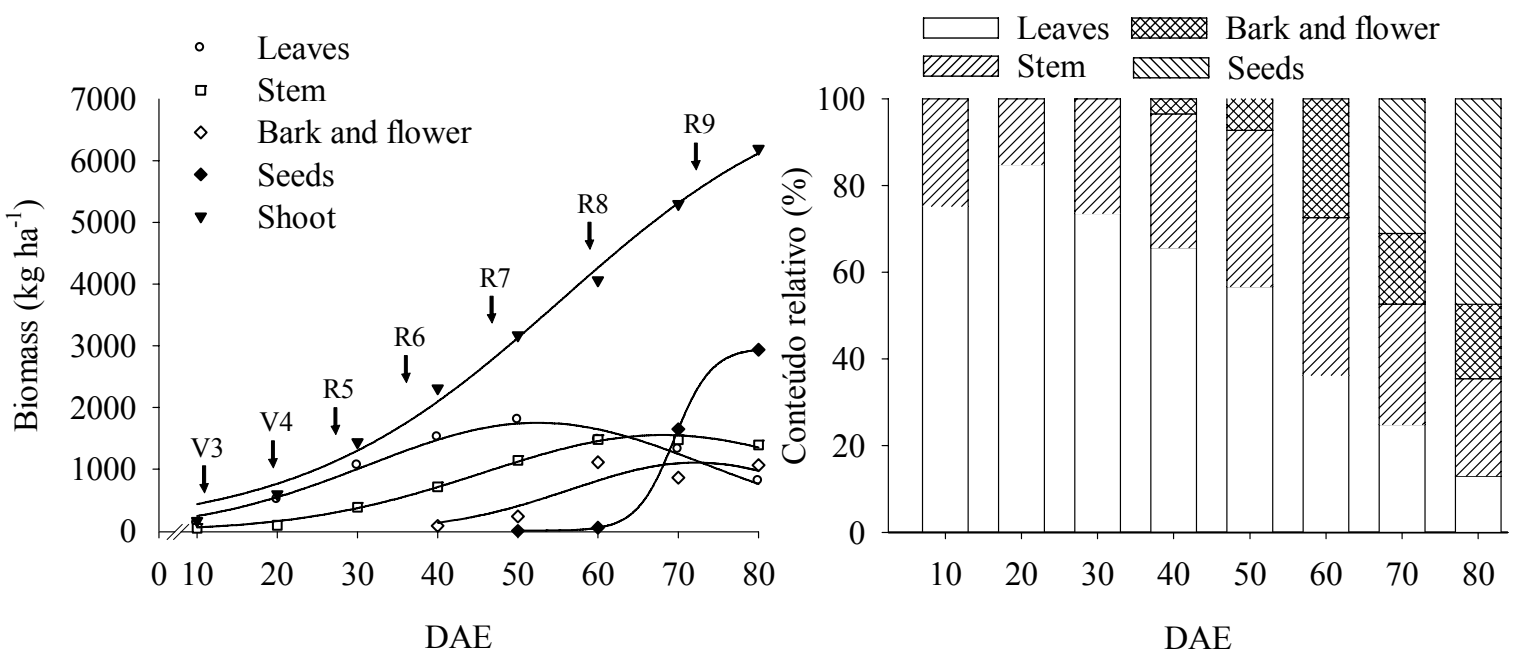

Figure 3. Production of biomass and relative content of biomass produced by the components of the shoot of the common bean (Leaf, stem, bark + flower and seeds) during the phenological cycle of the beans from the 2009 autumn/winter crop. V3 - First trifoliolate leaf; V4 - Third trifoliolate leaf; R5 - Pre-blooming; R6 - Blooming;

R7 - Formation of legumes; R8 - Filling of legumes; R9 - Maturation (first string starts to bleach or dry)

The maximum accumulation of $\mathrm{N}, \mathrm{P}$ and $\mathrm{K}$ in the shoot of the bean was observed at the end of the development cycle (80 DAE) and corresponded to 118,13 and $136 \mathrm{~kg} \mathrm{ha}^{-1}$, respectively (Figure 4). The components that presented the highest percentage of accumulation of these nutrients in the vegetative stages (V3 and V4) were the leaves with approximately $80 \%$ of the content of nutrients absorbed and, at the end of the reproductive stage (R5 through R9), comprise the seeds, with approximately $60 \%$ of the content of nutrients absorbed.

In general, between the 40 and $50 \mathrm{DAE}$ the content of N, P, K in the leaves decreased quickly and the process of accumulation of these nutrients in the reproductive components, bark, flower and seeds intensified up to the end of the crop cycle. 
The inflection point (IP), from which the maximum $\mathrm{N}$ accumulation rate by the shoot of the bean plant decreases, occurred on the $62 \mathrm{DAE}$ (stage R8), with accumulation rate of $2.30 \mathrm{~kg} \mathrm{ha}^{-1} \mathrm{day}^{-1}$ (Table 2); however, for leaves the maximum accumulation rate occurred on the $30 \mathrm{DAE}$, coinciding with the beginning of the development stage R5, and indicating the beginning of the $\mathrm{N}$ translocation-redistribution process of the leaves for the plant's reproductive organs (Figure 4). And the maximum content $\left(\mathrm{x}_{0}\right)$ of $\mathrm{N}$ absorbed by the components leaf and stem occurred on the $52 \mathrm{DAE}$ and $61 \mathrm{DAE}$, and corresponded to 29 and $22 \mathrm{~kg} \mathrm{ha}^{-1}$, respectively (Table 2). This period of maximum absorption of $\mathrm{N}$ was similar to the one found by Haag et al. (1967). These authors stated that, in the first 50 days, the bean plant absorbs the entire $\mathrm{N}$ needs. However, we observed in our study that, along with the translocation of $\mathrm{N}$ of the leaves we obtained accumulation of $\mathrm{N}$ in the shoot of the bean plant up to the end of the cultivation cycle (Figure 4). Corroborating with such results, Andrade et al. (2009) obtained maximum accumulation of $\mathrm{N}$ between 71 and $89 \mathrm{DAE}$ and maximum accumulation rate of $\mathrm{N}$ of 1.84 to $2.83 \mathrm{~kg} \mathrm{ha}^{-1} \mathrm{day}^{-1}$, indicating that the bean plant continues to absorb $\mathrm{N}$, even after blooming, whose beginning is normally the maximum limit considered to perform the conventional nitrogen fertilizations.

The maximum accumulation rate of $\mathrm{P}$ in the shoot occurred on the 48 DAE (stage R5) (Table 2) with an accumulation rate of $0.20 \mathrm{~kg} \mathrm{ha}^{-1} \mathrm{day}^{-1}$ similar to the results obtained by Vieira (2006), who found the peak and absorption between the 42 and $53 \mathrm{DAE}$ and the absorption rate of 0.200 and $0.320 \mathrm{~kg} \mathrm{ha}^{-1} \mathrm{day}^{-1}$, working with conventional and no-tillage farming, respectively. The maximum percentage of $\mathrm{P}$ accumulated in the leaves occurred in the first $10 \mathrm{DAE}$, indicating its high demand in the initial period of cultivation for vegetative production and immediate translocation of $\mathrm{P}$ of the leaves after the 10 DAE. At the end of the cultivation cycle, the bean accumulated $14 \mathrm{~kg} \mathrm{ha}^{-1}$ of $\mathrm{P}$ in the shoot, and $56 \%$ out of these $\left(8 \mathrm{~kg} \mathrm{ha}^{-1}\right)$ were exported from the cultivation area as seeds.

Table 2. Estimated parameters of the adjusted model for biomass of dry matter and course of absorption of macronutrients $\mathrm{N}, \mathrm{P}$ and $\mathrm{K}$

\begin{tabular}{|c|c|c|c|c|c|c|}
\hline \multirow{2}{*}{ Plant part } & \multicolumn{3}{|c|}{ Estimated parameters of adjusted model } & \multirow{2}{*}{$\begin{array}{c}\text { IP } \\
\left(X_{0}-b\right)\end{array}$} & \multirow{2}{*}{ Stage } & \multirow{2}{*}{$\mathrm{R}^{2}$} \\
\hline & $\mathrm{a}$ & $\mathrm{X}_{0}$ & $\mathrm{~b}$ & & & \\
\hline & \multicolumn{6}{|c|}{ Dry matter biomass } \\
\hline Leaf $^{\mathrm{n}^{\circ}}$ & $1,750.96$ & 52.47 & 21.25 & 31.22 & R5-R6 & 0.97 \\
\hline $\operatorname{Stem}^{\mathrm{n}^{\mathrm{v}}}$ & $1,552.15$ & 68.13 & 22.46 & 45.67 & R6-R7 & 0.99 \\
\hline Bark and flower ${ }^{\#}$ & $1,105.77$ & 72.15 & 15.54 & 56.61 & $\mathrm{R} 7-\mathrm{R} 8$ & 0.80 \\
\hline Seeds ${ }^{\star}$ & $2,967.82$ & 69.49 & 2.33 & 69.49 & R8-R9 & 0.99 \\
\hline \multirow[t]{2}{*}{ Shoot $^{\star}$} & $7,458.25$ & 55.28 & 16.24 & 55.28 & R7-R8 & 0.99 \\
\hline & \multicolumn{6}{|c|}{ Nitrogen } \\
\hline Leaf $^{\#}$ & 29.05 & 52.43 & 22.61 & 29.82 & R5-R6 & 0.92 \\
\hline Stem $^{\#^{v}}$ & 21.90 & 61.18 & 19.54 & 41.64 & R6-R7 & 0.99 \\
\hline Bark and flower ${ }^{\#}$ & 20.01 & 67.66 & 14.53 & 53.13 & R7-R8 & 0.65 \\
\hline Seeds ${ }^{\star}$ & 73.81 & 68.95 & 1.80 & 68.95 & R8-R9 & 0.99 \\
\hline \multirow[t]{2}{*}{ Shoot $^{\&}$} & 162.48 & 62.03 & 17.61 & 62.03 & R8-R9 & 0.99 \\
\hline & \multicolumn{6}{|c|}{ Phosphorus } \\
\hline Leaf $^{\#}$ & 5.32 & 44.49 & 16.50 & 27.99 & R5-R6 & 0.96 \\
\hline Stem $^{\#^{v}}$ & 2.43 & 57.59 & 18.15 & 39.44 & R6-R7 & 0.99 \\
\hline Bark and flower & 2.32 & 70.55 & 13.91 & 56.64 & $\mathrm{R} 7-\mathrm{R} 8$ & 0.80 \\
\hline Seeds ${ }^{\star}$ & 8.05 & 68.36 & 1.50 & 68.36 & R8-R9 & 0.99 \\
\hline \multirow[t]{2}{*}{ Shoot $^{\star}$} & 14.33 & 47.97 & 18.00 & 47.97 & R7-R8 & 0.94 \\
\hline & \multicolumn{6}{|c|}{ Potassium } \\
\hline Leaf $^{\#}$ & 37.50 & 50.59 & 19.97 & 30.61 & R6 & 0.78 \\
\hline Stem $^{\#}$ & 31.05 & 69.43 & 23.38 & 46.05 & R6 & 0.97 \\
\hline Bark and flower ${ }^{\#}$ & 20.00 & 67.73 & 14.60 & 53.13 & R7 & 0.65 \\
\hline Seeds ${ }^{\alpha}$ & 74.68 & 68.87 & 2.07 & 68.87 & R8-R9 & 0.99 \\
\hline Shoot $^{\star}$ & 175.01 & 59.11 & 17.44 & 59.11 & R7-R8 & 0.97 \\
\hline
\end{tabular}

\footnotetext{
\#: Gaussian model adjustment. ${ }^{\&}$ : Sigmoid model adjustment
} 
The content of $\mathrm{K}$ absorbed by the shoot of the bean plant was similar to that of the $\mathrm{N}$, being observed the maximum accumulation rate of $\mathrm{K}$ between the development stages R7-R8 (59 DAE), and corresponded to $2.5 \mathrm{~kg} \mathrm{ha}^{-1} \mathrm{day}^{-1}$ (Table 2 and Figure 4). Such results were considered superior to those found by Andrade et al. (2009), where the maximum accumulation rate was observed on the 40 DAE.
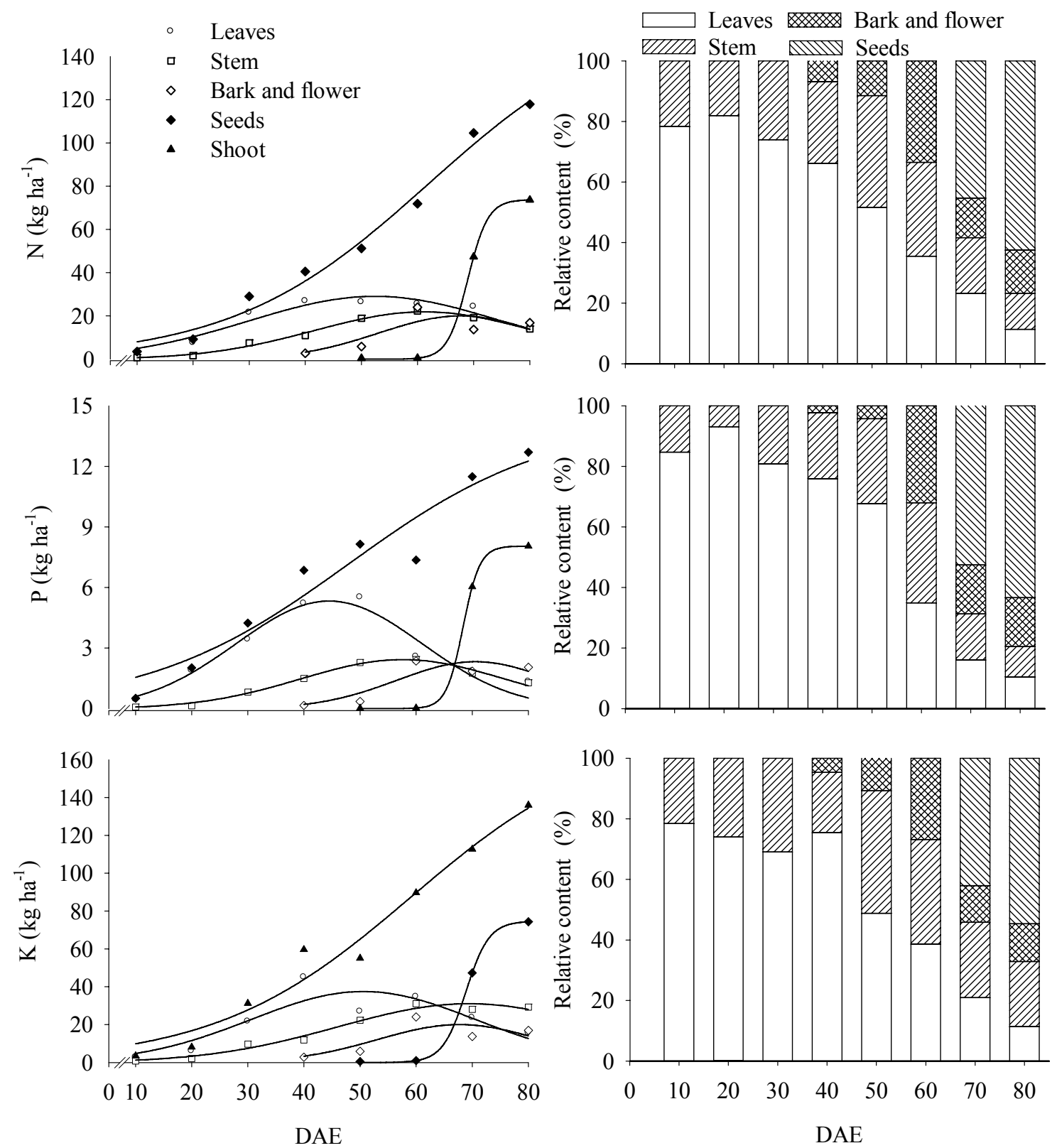

Figure 4. Course of absorption and relative accumulation of N, P and $\mathrm{K}$ in the plant components (leaf, stem, bark + flower, seeds) and in the shoot during the development of the common bean irrigated north of the state of Minas

Gerais

\subsection{Absorption of $\mathrm{Ca}, \mathrm{Mg}$ and $\mathrm{S}$ during the Common Bean Development Cycle}

Through the adjusted regression models, it was possible to observe that the absorption of $\mathrm{Ca}, \mathrm{Mg}$ and $\mathrm{S}$ in the shoot of the bean was intensified as from the $20 \mathrm{DAE}$, and achieved maximum accumulation of $\mathrm{Ca}, \mathrm{Mg}$ and $\mathrm{S}$ in the leaves on the 46-48 DAE, with 43.8; 6.3 and $5.2 \mathrm{~kg} \mathrm{ha}^{-1}$, respectively (Table 3 and Figure 5). The maximum accumulation rate in the shoot of the bean was $1.60 \mathrm{~kg} \mathrm{ha}^{-1} \mathrm{day}^{-1}$ for Ca and $0.23 \mathrm{~kg} \mathrm{ha}^{-1} \mathrm{day}^{-1}$ for Mg on the $36 \mathrm{DAE}$ and, for $\mathrm{S}$, of $0.40 \mathrm{~kg} \mathrm{ha}^{-1} \mathrm{day}^{-1}$ on the $76 \mathrm{DAE}$. 
When evaluating the distribution of $\mathrm{Ca}, \mathrm{Mg}$ and $\mathrm{S}$ in the components of bean, we observed accumulation superior to $90 \%$ on the $30 \mathrm{DAE}$ for $\mathrm{Ca}$ and $\mathrm{Mg}$, and $60 \%$ for $\mathrm{S}$, in the leaves. After the $30 \mathrm{DAE}$ and with the uprising of the first reproductive organs, we obtained proportional reduction in the accumulation of $\mathrm{Ca}, \mathrm{Mg}$ and $\mathrm{S}$ in the vegetative organs and increments in the reproductive ones, reaching approximately $50 \%$ of $\mathrm{Ca}$ and $\mathrm{Mg}$, and $60 \%$ of $\mathrm{S}$ accumulated in the seeds, at the end of the common bean cycle (Figure 5).

During the reproductive stage, the leaves consisted in the main source of redistribution of $\mathrm{Mg}$, while for $\mathrm{S}$, although small, the redistribution occurred from the stem (Figure 5). And, for $\mathrm{Ca}$, the redistribution for the reproductive organs was very low, resulting in only $15 \%$ of the total accumulated at the end of the cycle.

Table 3. Estimated Parameters of the Adjusted Model for Biomass of Course of Absorption of Macronutrients Ca, $\mathrm{Mg}$ and $\mathrm{S}$

\begin{tabular}{|c|c|c|c|c|c|c|}
\hline \multirow{2}{*}{ Plant part } & \multicolumn{3}{|c|}{ Estimated parameters of adjusted model } & \multirow{2}{*}{$\begin{array}{c}\text { IP } \\
\left(\mathrm{X}_{0-} \mathrm{b}\right)\end{array}$} & \multirow{2}{*}{ Stage } & \multirow{2}{*}{$\mathrm{R}^{2}$} \\
\hline & $\mathrm{a}$ & $\mathrm{X}_{0}$ & $\mathrm{~b}$ & & & \\
\hline & \multicolumn{6}{|c|}{ Calcium } \\
\hline Leaf $^{\#}$ & 43.80 & 47.55 & 17.88 & 29.67 & R5-R6 & 0.93 \\
\hline Stem $^{\#}$ & 11.67 & 65.58 & 20.11 & 45.47 & R6-R7 & 0.97 \\
\hline Bark and flower ${ }^{\#}$ & 17.95 & 74.87 & 16.05 & 58.82 & R7- R8 & 0.91 \\
\hline Seeds ${ }^{\&}$ & 39.73 & 69.64 & 2.31 & 69.64 & R8-R9 & 0.99 \\
\hline \multirow[t]{2}{*}{ Shoot ${ }^{\&}$} & 73.72 & 35.76 & 11.56 & 35.76 & R7- R8 & 0.94 \\
\hline & \multicolumn{6}{|c|}{ Magnesium } \\
\hline Leaf $^{\#}$ & 6.25 & 47.54 & 17.88 & 29.66 & R5-R6 & 0.93 \\
\hline Stem $^{\#}$ & 1.66 & 65.58 & 20.11 & 45.47 & R6-R7 & 0.97 \\
\hline Bark and flower ${ }^{\#}$ & 2.56 & 74.87 & 16.05 & 58.82 & R7- R8 & 0.91 \\
\hline Seeds ${ }^{\&}$ & 5.77 & 69.66 & 2.90 & 69.66 & R8-R9 & 0.99 \\
\hline \multirow[t]{2}{*}{ Shoot ${ }^{\&}$} & 10.53 & 35.76 & 11.57 & 35.76 & R7- R8 & 0.94 \\
\hline & \multicolumn{6}{|c|}{ Sulphur } \\
\hline Leaf $^{\#}$ & 5.22 & 46.31 & 17.80 & 28.51 & R5-R6 & 0.74 \\
\hline Stem $^{\#}$ & 4.83 & 66.46 & 23.50 & 42.96 & R6-R7 & 0.95 \\
\hline Bark and flower ${ }^{\#}$ & 2.98 & 65.95 & 14.11 & 51.84 & R7- R8 & 0.62 \\
\hline Seeds ${ }^{\&}$ & 12.79 & 69.88 & 3.08 & 69.88 & R8-R9 & 0.99 \\
\hline Shoot ${ }^{\&}$ & 37.14 & 75.67 & 23.15 & 75.67 & R8-R9 & 0.96 \\
\hline
\end{tabular}

${ }^{\#}$ : Gaussian model adjustment. ${ }^{\&}$ : Sigmoid model adjustment. 

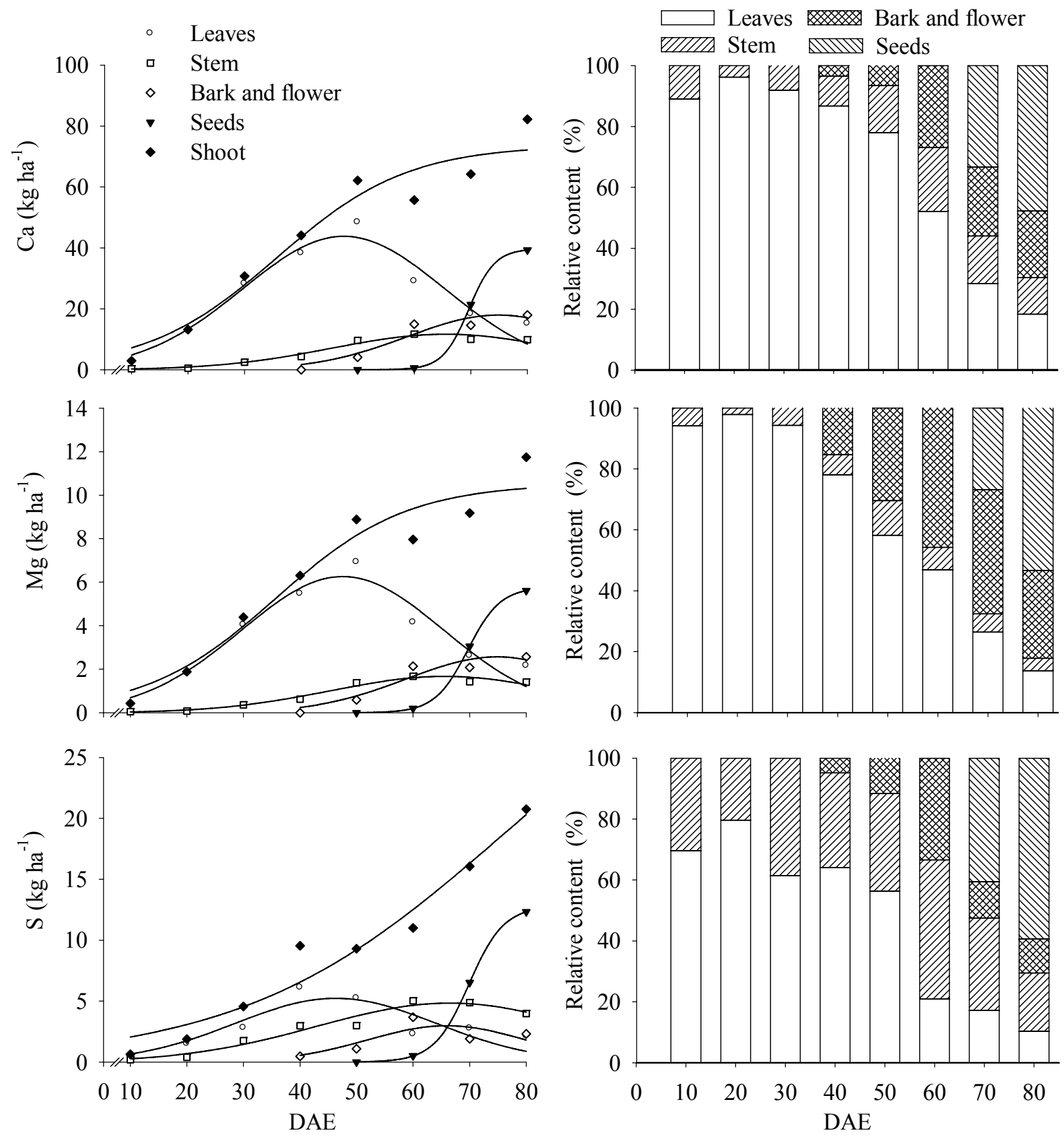

Figure 5. Course of absorption and relative accumulation of $\mathrm{Mg}, \mathrm{Ca}$ and $\mathrm{S}$ in the plant components (leaf, stem, bark + flower, seeds) and in the shoot during the development of the common bean irrigated north of the state of Minas Gerais

\subsection{Export of Macronutrients by Common Bean}

In this study, the estimated production of seeds was $2,967.8 \mathrm{~kg} \mathrm{ha}^{-1}$ corresponding to export of $\mathrm{N}, \mathrm{P}, \mathrm{K}, \mathrm{Ca}, \mathrm{Mg}$ and $\mathrm{S}$ to the order of $73.8 ; 8.1 ; 74.7 ; 39.7 ; 5.8$ and $12.8 \mathrm{~kg} \mathrm{ha}^{-1}$, (Table 2 and Table 3 ). Such exports were regarded as superior to those found by Pessoa et al. (2000), who obtained estimated productivity of $1,893 \mathrm{~kg} \mathrm{ha}^{-1}$ of seeds and exports of N, P, K, Ca, Mg and S corresponding to 72; 9.4; 15.3; 15.7; 4.0; $0.1 \mathrm{~kg} \mathrm{ha}^{-1}$ and by Araújo \& Teixeira (2008) who obtained accumulation of $\mathrm{N}$ and $\mathrm{P}$, ranging from 54 to $64 \mathrm{~kg} \mathrm{ha}^{-1}$ and from 4.5 to $6.9 \mathrm{~kg} \mathrm{ha}^{-1}$ in 1998 and 1999 for average productivity of 1,130 to $1,710 \mathrm{~kg} \mathrm{ha}^{-1}$.

Due to the results described in the paragraph above, we suggest that the largest portion of the nutrients absorbed by 
the bean may be exported from the cultivation are by the seeds, as, in comparison, the total absorption of macronutrients by the bean at the end of the cycle, we obtained the following percentages of export of $\mathrm{N}, \mathrm{P}, \mathrm{K}, \mathrm{Ca}$, $\mathrm{Mg}$ and S (seeds), respectively: 63, 63, 55, 48, 49 and 62\%, indicating that $\mathrm{N}$ and $\mathrm{P}$ are the nutrients exported in largest proportion by the bean, followed by S and K. Proportionally, the nutrients less exported by the crop were $\mathrm{Ca}$ and Mg. Second Fageria et al. (2008) the rate of export of N and P in grain bean was greater than $90 \%$ of the total absorbed by plants, indicating a high capacity of translocation of $\mathrm{N}$ and $\mathrm{P}$ in the bean compared with other macronutrients.

In order to produce one tone of bean seeds in this study, we accumulated in the shoot of the common bean $39.7 \mathrm{~kg}$ of N, $4.3 \mathrm{~kg}$ of P, $45.8 \mathrm{~kg}$ of K, $27.7 \mathrm{~kg}$ of Ca, $4.0 \mathrm{~kg}$ of Mg and $7.0 \mathrm{~kg}$ of S. Such accumulations were considered superior to those obtained by Albuquerque et al. (2011a) and Albuquerque et al. (2011b), for K (33.9 kg), Ca (17.1) and $\mathrm{S}(3.2 \mathrm{~kg})$ and inferior to those obtained for $\mathrm{N}(57.9 \mathrm{~kg}), \mathrm{P}(6.6 \mathrm{~kg})$ and $\mathrm{Mg}(6.4 \mathrm{~kg})$ per ton of seeds of $\mathrm{cv}$. Jalo EEP 558, cultivated under conventional system in the Brazilian cerrado. The performance of new studies for irrigated cultivations in the Brazilian semi-arid is necessary, due to the high productive potential and variations obtained in the capacity of extraction of nutrients by the common bean.

\section{Conclusions}

The absorption of $\mathrm{N}, \mathrm{K}$ and $\mathrm{Ca}$ is incremented with the addition of intermediate doses of $\mathrm{N}\left(40\right.$ and $\left.80 \mathrm{~kg} \mathrm{ha}^{-1}\right)$ in sidedressing. The $\mathrm{N}$ doses, both in seedling and sidedressing, do not interfere in the absorption of $\mathrm{P}, \mathrm{Mg}$ and $\mathrm{S}$ by the rainy season beans. However, higher doses than $80 \mathrm{~kg} \mathrm{ha}^{-1}$ of $\mathrm{N}$ (urea source) in sidedressing is not recommended because of the competitive inhibition of $\mathrm{N}, \mathrm{K}$, and $\mathrm{Ca}$ uptake, what can be reduce bean development.

The absorption of nutrients in the common bean crop and the export of seeds follow the top-down order below: $\mathrm{K}>\mathrm{N}>\mathrm{Ca}>\mathrm{S}>\mathrm{P}>\mathrm{Mg}$, and corresponds to the total accumulation in the shoot, respectively, of 136,118, 82, 21, 13 and $12 \mathrm{~kg} \mathrm{ha}^{-1}$. Such total accumulation and relationship between nutrients in bean shoot should be considered as reference values, regarding nutritional crop requirements in future programs of corrective and fertilizer recommendation.

The seeds is the component of plant with highest macronutrients accumulation in relation a shoot of plant and is obtained the following top-down order of relative macronutrients export by seeds: $\mathrm{N}=\mathrm{P}>\mathrm{S}>\mathrm{K}>\mathrm{Ca}>\mathrm{Mg}$. The export of $\mathrm{N}, \mathrm{P}$ and $\mathrm{S}$ is above $60 \%$ of total accumulation in bean shoots and were the nutrients with lower relative rate of cycling to subsequent crops. The high nutritional $\mathrm{N}$ demand of common bean, combined with high export rate of irrigated systems require studies aimed $\mathrm{N}$ doses adjustment for bean crops in semiarid regions.

The maximum accumulation rate of macronutrients in the common bean leaves is situated between 28 and 31 DAE (R5-R6 stages) and in the shoot, is situated between 30 and 40 DAE (R6-R7 stages) for Ca and Mg, and between 50 and 60 DAE (R7-R8 stages) for N, P and K. As a result of this work and for an effective fertilizer use, it is recommended to management practices between 20 and 30 DAE of irrigated bean, because this period precedes and match with the greater nutritional demand phase (maximum nutrient accumulation rate) by the bean leaves, where they are photoassimilate production.

\section{References}

Albuquerque, A., Oliveira, D. P., Vieira, N. M. B., Andrade, C. A. B., \& Andrade, M. J. B. (2011a). Partitioning of dry matter, nitrogen, phosphorus and potassium in bean genotypes. Annual Report of the Bean Improvement Cooperative, 54, 176-177.

Albuquerque, A., Oliveira, D. P., Vieira, N. M. B., Andrade, C. A. B., \& Andrade, M. J. B. (2011b). Partitioning of dry matter, calcium, magnesium and sulfur in bean genotypes. Annual Report of the Bean Improvement Cooperative, 54, 174-175.

Albuquerque, H. C., Pegoraro, R. F., Vieira, N. M. B., Amorim, S. J. F., \& Kondo, M. K. (2012). Capacidade nodulatória e características agronômicas de feijoeiros comuns submetidos à adubação molíbdica parcelada $\mathrm{e}$ $\begin{array}{lllll}\text { nitrogenada. } & \text { Revista } & \text { Ciência } & \text { Agronômica, } & 43,\end{array}$ http://dx.doi.org/10.1590/S1806-66902012000200002

Andrade, M. J. B., Vieira, N. M. B., Carvalho J. G., Alves Junior, J., Moraes, A. R., \& Rezende, P. M. (2009). Pattern of macronutrients absorption by common bean cvs. BRS MG Talismä and Ouro Negro at conventional and no till systems. Annual Report of the Bean Improvement Cooperative, 52, 120-121. 
Anghinoni, I. (2007). Fertilidade do solo e seu manejo no sistema plantio direto. In R. F. Novais, V. V. H. Alvarez, N. F. Barros, R. L. F. Fontes, R. B. Cantarutti, J. C. L. Neves (Org.). Fertilidade do Solo. $1^{\text {a }}$ ed. Viçosa: Sociedade Brasileira de Ciência do Solo, 1, 873-928.

Araújo, A. P., \& Teixeira, M. G. (2008). Relationships between grain yield and accumulation of biomass, nitrogen and phosphorus in common bean cultivars. Revista Brasileira de Ciência do Solo, 32, 1977-1986. http://dx.doi.org/10.1590/S0100-06832008000500019

Arf, O., Rodrigues, R. A. F., Sá, M. E., Buzetti, S., \& Nascimento, V. (2004). Manejo do solo, água e nitrogênio no cultivo de feijão. Pesquisa Agropecuária Brasileira, 39, 131-138. http://dx.doi.org/10.1590/S0100-204X2004000200005

Aulakh, M. S., \& Malhi, S. S. (2005). Interactions of Nitrogen with Other Nutrients and Water: Effect on Crop Yield and Quality, Nutrient Use Efficiency, Carbon Sequestration, and Environmental Pollution. Advances in Agronomy, 86, 341-409. http://dx.doi.org/10.1016/S0065-2113(05)86007-9

Bataglia, O. C., Furlani, A. C. M., Teixeira, J. P. F., Furlani, P. R., \& Gallo, J. R. (1983). Métodos de análises químicas de plantas. Campinas: Instituto Agronômico.

Bertsch, F., Hernández, J. C., Arguedas, F., \& Acosta, M. (2003). Curvas de absorción de nutrimentos en dos variedades, Bribri y Sacapobres, de Frijol Común de Grano Rojo. Agronomía Costarricense, 27, 75-81.

Brito, M. M. P., Muraoka, T., \& Silva, E. C. (2009). Marcha de absorção do nitrogênio do solo, do fertilizante e da fixação simbiótica em feijão-caupi (Vigna unguiculata (L.) walp.) e feijão-comum (Phaseolus vulgaris L.) determinada com uso de ${ }^{15} \mathrm{~N}$. Revista Brasileira de Ciência do Solo, 33, 895-905. http://dx.doi.org/10.1590/S0100-06832009000400014

Britto, D. T., \& Kronzucker, H. J. (2006). Plant Nitrogen Transport and Its Regulation in Changing Soil Environments. Journal of Crop Improvement, 15, 1-23. http://dx.doi.org/10.1300/J411v15n02_01

Britto, D. T., Siddiqi, M. Y., Glass, A. D. M., \& Kronzucker, H. J. (2001). Futile transmembrane NH $^{4+}$ cycling: a cellular hypothesis to explain ammonium toxicity in plants. Proceedings of the National Academy of Sciences, USA, 98, 4255-4258.

Carvalho, M. A. C., Furlani Junior, E., Arf, O., Sá, M. E., Paulino, H. B., \& Buzetti, S. (2003). Doses e épocas de aplicação de nitrogênio e teores foliares deste nutriente e de clorofila em feijoeiro. Revista Brasileira de Ciência do Solo, 27, 445-450. http://dx.doi.org/10.1590/S0100-06832003000300006

Chagas, J. M., Braga, J. M., Vieira, C., Salgado, L. T, Junqueira Neto, A., Araújo, G. A. A., Andrade, M. J. B., Lana, R. M. Q., \& Ribeiro, A. C. (1999). Feijão. In Ribeiro, A.C., Guimarães, P. T. G., Alvarez, V.H (Org.). Recomendações para o uso de corretivos e fertilizantes em Minas Gerais - $5^{a}$ Aproximação. Viçosa: Comissão de Fertilidade do Solo do Estado de Minas Gerais (pp. 306-307).

Embrapa. (1997). Empresa Brasileira de Pesquisa Agropecuária. Centro Nacional de Pesquisa de Solos. Manual de métodos de análise de solo (2nd ed.). Rio de Janeiro: Embrapa Solos, p. 212.

Embrapa. (2006). Empresa Brasileira de Pesquisa Agropecuária. Centro Nacional de Pesquisa de Solos. Sistema Brasileiro de Classificação de Solos. Rio de Janeiro: Embrapa Solos (p. 306).

Fageria, N. K. (2002). Nutrient management for sustainable dry bean production in the tropics. Communications in Soil Science and Plant Analysis, 33, 1537-1575. http://dx.doi: 10.1081/CSS-120004299

Fageria, N. K., \& Baligar, V. C. (2005). Enhancing nitrogen use efficiency in crop plants. Advances in Agronomy, 88, 97-185. http://dx.doi.org/10.1016/S0065-2113(05)88004-6

Fageria, N. K., Stone, L. F., \& Moreira, A. (2008). Liming and manganese influence on common bean yield, nutrient uptake, and changes in soil chemical properties of an Oxisol under no-tillage system. Journal of Plant Nutrition, 31, 1723-1735. http://dx.doi.org/10.1080/01904160802324720

Farinelli, R., Lemos, L. B., Penariol, F. G., Egéa, M. M., \& Gasparoto, M. G. (2006). Adubação nitrogenada de cobertura no feijoeiro, em plantio direto e convencional. Pesquisa agropecuária brasileira, 41, 307-312. http://dx.doi.org/10.1590/S0100-204X2006000200016

Ferreira, D. F. (2000). Sistema de análises de variância para dados balanceados (SISVAR 4.1). Lavras: Universidade Federal de Lavras.

Haag, H. P., Malavolta, E., Gargantini, H., \& Garcia Blanco, H. (1967). Absorção de nutrientes pela cultura do feijoeiro. Bragantia, 26, 381-391. http://dx.doi.org/10.1590/S0006-87051967000100030 
Holzschuh, M. J., Bohnen, H., Ibanor Anghinoni, I., Meurer, E. J., Carmona, F. C., \& Costa, S. E. V. G. A. (2009). Resposta do arroz irrigado ao suprimento de amônio e nitrato. Revista Brasileira de Ciência do Solo, 33, 1323-1331. http://dx.doi.org/10.1590/S0100-06832009000500025

Hoopen, F. T., Cuin, T. A., Pedas, P., Hegelund, J. N., Shabala, S., Schjoerring, J. K., \& Jahn, T. P. (2010). Competition between uptake of ammonium and potassium in barley and Arabidopsis roots: molecular mechanisms and physiological consequences. Journal of Experimental Botany, 61, 2303-2315. http://dx.doi.org/10.1093/jxb/erq057

INMET. (2012). Instituto Nacional De Meteorologia. Banco de dados meteorológicos para ensino e pesquisa. Retrieved September 29, 2012, from http://www.inmet.gov.br/portal/index.php?r= bdmep/bdmep

Kaneko, F. H., Arf, O., Gitti, D. C., Arf, M. V., Ferreira, J. P., \& Buzetti, B. (2010). Mecanismos de abertura de sulcos, inoculação e adubação nitrogenada em feijoeiro em sistema plantio direto. Bragantia, 69, 125-133. http://dx.doi.org/10.1590/S0006-87052008000200026

Kikuti, H., Andrade, M. J. B., Carvalho, J. G., \& Morais, A. R. (2006). Teores de macronutrientes na parte aérea do feijoeiro em função de doses de nitrogênio e fósforo. Bragantia, 65, 347-354. http://dx.doi.org/10.1590/S0006-87052006000200017

Kronzucker, H. J., Britto, D. T., Davenport, R. J., \& Tester, M. (2001). Ammonium toxicity and the real cost of transport. Trends in Plant Science, 6, 335-337. http://dx.doi.org/10.1016/S1360-1385(01)02022-2

Lima, E. V., Aragão, C. A., Morais, O. M., Tanaka, R., \& Filho, H. G. (2001). Adubação NK no desenvolvimento e na concentração de macronutrientes no florescimento do feijoeiro. Scientia Agricola, 58, 125-129. http://dx.doi.org/10.1590/S0103-90162001000100019

Maia, S. C. M., Soratto, R. P., Nastaro, B., \& Freitas, L. B. (2012). The nitrogen sufficiency index underlying estimates of nitrogen fertilization requirements of common bean. Revista Brasileira de Ciência do Solo, 36, 183-191. http://dx.doi.org/10.1590/S0100-06832012000100019

Malavolta, E., Vitti, G. C., \& Oliveira, S. A. (1997). Avaliação do estado nutricional das plantas, princípios e aplicações (2nd ed.). Piracicaba: Potafos, 319 p.

Martinez, H. E. P., Carvalho, J. G. \& Souza, R. B. (1999). Diagnose foliar. In A. C. Ribeiro, P. T. G.Guimarães, \& V. V. H. Alvarez (Eds.), Recomendações para o uso de corretivos e fertilizantes em Minas Gerais - $5^{a}$ Aproximação (pp. 143-168). Viçosa: Comissão de Fertilidade do Solo do Estado de Minas Gerais.

Nascimento, M. S., Arf, O., Barbosa, G. F., Buzetti, S. Nascimento, R. S., \& Castro, R. M. (2009). Nitrogênio em cobertura e molibdênio via foliar em feijoeiro de inverno no sistema plantio direto II - Características agronômicas e produtividade. Scientia Agraria, 10, 351-358

Neves, A. L. R., Lacerda, C. F., Guimarães, F. V. A., Hernandez, F. F. F., Silva, F. B., Prisco, J. T., \& Gheyi, H. R. (2009). Acumulação de biomassa e extração de nutrientes por plantas de feijão-de-corda irrigadas com água salina em diferentes estádios de desenvolvimento. Ciência Rural, 39, 758-765. http://dx.doi.org/10.1590/S0103-84782009005000014

Oliveira, A. P., Silva, V. R. F., Arruda, F. P., Nascimento, I. S., \& Alves, A. U. (2003). Rendimento de feijão-caupi em função de doses e formas de aplicação de nitrogênio. Horticultura Brasileira, 21, 77-80. http://dx.doi.org/10.1590/S0102-05362003000100016

Oliveira, T. K., Carvalho, G. J., \& Moraes, R. N. S. (2002). Plantas de cobertura e seus efeitos sobre o feijoeiro em plantio direto. Pesquisa Agropecuária Brasileira, 1079-1087. http://dx.doi.org/10.1590/S0100-204X2002000800005

Ometto, J. C. (1981). Classificação Climática. In: Ometto, J. C. Bioclimatologia tropical (pp. 390-398). São Paulo: Ceres.

Pessoa, A. C. S., Ribeiro, A. C., Chagas, J. M., \& Cassini, S. T. A. (2000). Concentração foliar de molibdênio e exportação de nutrientes pelo feijoeiro "Ouro Negro" em resposta à adubação foliar com molibdênio. Revista Brasileira de Ciência do Solo, 24, 75-84.

Rajesh, C., McDonald, L. M., \& Bryan, W. B. (2012a). Optimization of water potential and nutrient levels for Kentucky bluegrass - white clover mixture on acidic soils. Biotechnology, Agronomy, Society and Environment, 16, 167-177. 
Rajesh, C., McDonald, L. M., \& Bryan, W. B. (2012b). Effect of soil water and nutrients on productivity of Kentucky bluegrass system in acidic soils. Journal of Plant Nutrition, 35, 288-303. http://dx.doi.org/10.1080/01904167.2012.636131

Sant'ana, E. V. P., Santos, A. B., \& Silveira, P. M. (2011). Eficiência de uso de nitrogênio em cobertura pelo feijoeiro irrigado. Revista Brasileira de Engenharia Agrícola e Ambiental, 15, 458-462. http://dx.doi.org/10.1590/S1415-43662011000500004

Santos, A. B., \& Fageria, N. K. (2007). Manejo do nitrogênio para eficiência de uso por cultivares de feijoeiro em

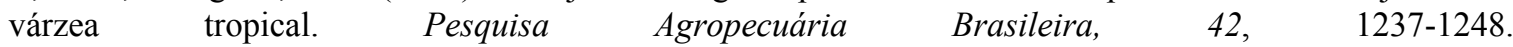
http://dx.doi.org/10.1590/S0100-204X2007000900004

Szczerba, M. W., Britto, D. T., Ali, S. A., Balkos, K. D., \& Kronzucker, H. J. (2008). $\mathrm{NH}_{4}{ }^{+}$stimulated and inhibited components of $\mathrm{K}^{+}$transport in rice (Oryza sativa L.). Journal of Experimental Botany, 59, 3415-3423. http://dx.doi.org/10.1093/jxb/ern190

Teixeira, C. M., Carvalho, G. J., Silva, C. A., Andrade, M. J. B., \& Paes, J. M. V. (2010). Nutrição mineral do feijoeiro sob influência de nitrogênio e palhadas de milheto solteiro e consorciado com crotalária. FAZU em Revista, 7, 73-79.

Vieira, N. M. B. (2006). Crescimento e marcha de absorção de nutrientes no feijoeiro cvs. BRS-MG Talismã e Ouro Negro, em plantio direto e convencional. Dissertação (Mestrado em Fitotecnia), Universidade Federal de Lavras, Lavras, MG.

Westermann, D. T., Terán, H., Muñoz-Perea, C. G., \& Singh, S. P. (2011). Plant and seed nutrient uptake in common bean in seven organic and conventional production systems. Canadian Journal of Plant Science, 91, 1089-1099. http://dx.doi.org/10.4141/CJPS10114

Zucareli, C., Prando, A. M., Ramos Junior, E. U., \& Nakagawa, J. (2011). Fósforo na produtividade e qualidade de sementes de feijão Carioca Precoce cultivado no período das águas. Revista Ciência Agronômica, 42, 32-38. http://dx.doi.org/10.1590/S1806-66902011000100005

Zucareli, C., Ramos Junior, E. U., Barreiro, A. P., Nakagawa, J., \& Cavariani, C. (2006). Adubação fosfatada, componentes de produção, produtividade e qualidade fisiológica em sementes de feijão. Revista Brasileira de Sementes, 28, 5-15. http://dx.doi.org/10.1590/S0101-31222006000100002

\section{Copyrights}

Copyright for this article is retained by the author(s), with first publication rights granted to the journal.

This is an open-access article distributed under the terms and conditions of the Creative Commons Attribution license (http://creativecommons.org/licenses/by/3.0/). 